\title{
Peramalan Volume Penjualan Buah Jambu Biji Merah (Psidium Guajava Linn.) di CV Moena Abadi Sejahtera 1
}

\author{
IDA AYU PREMAYANTI, I WAYAN WIDYANTARA, \\ RATNA KOMALA DEWI
}

\author{
Program Studi Agribisnis, Fakultas Pertanian, Universitas Udayana \\ JL. PB Sudirman Denpasar 80323 \\ E-mail: dayuprema@gmail.com \\ widyantaramkr@gmail.com
}

\begin{abstract}
Sales Volume Forecasting Red Guava Fruit (Psidium Guajava Linn.) in CV Moena Abadi Sejahtera 1
\end{abstract}

This study aims to determine the factors that affect the sales volume of fruit Guava Red and estimating sales volume Guava fruit Red 2016, 2017, and 2018 in CV Moena Abadi Sejahtera 1. The data were taken within the last six years the year 2010 until 2015. this study used two models of the sales function is a linear function of sales and sales functions are transformed into a form logharitma tested with three criteria to get the best sales function model. The independent variables that affect the price of fruit Guava Red (PJBM), the price of fruit Bark (PSB), the price of fruit Ambon Banana (PPA), the price fruit Lumajang Oranges (PJL), and the price fruits Kintamani oranges (PJK). Sales function model which is transformed into the shape of a model function logharitma valid sales are LogQJBM $=-7.267-0,227 \log \mathrm{PJBM}_{\text {+ }}+$ $1,798 \log \mathrm{P}_{\mathrm{SB}}-0,102 \log \mathrm{P}_{\mathrm{PA}}+0,136 \log \mathrm{P}_{\mathrm{JL}}+0,379 \log \mathrm{P}_{\mathrm{JK}} \pm$ e. Factors that influence is Red Guava fruit prices, the price of fruit Salak Bali, Lumajang Citrus fruit prices, and the price Citrus fruits Kintamani. Estimated sales of Red Guava fruit using trend analysis and multiple linear regression to see the value of the coefficient of determination (R2), the largest and the value of the standard error (SE), the smallest so get the best forecasting method. Methods exponential trend is the best forecasting method is $\mathrm{Y}=502.34+1.0023 \mathrm{t} \pm \mathrm{e}$. The estimation results of the Red Guava fruit sales in 2016, 2017, and 2018 continue to rise. CV Moena Abadi Sejahtera 1 should use a forecasting method to maintain the availability of the fruit in the store, especially the Red Guava fruit.

Keywords: sales, red guava fruit, price, estimates

\section{Pendahuluan}

\subsection{Latar Belakang}

Indonesia merupakan salah satu negara penghasil buah tropis yang memiliki keanekaragaman dan keunggulan cita rasa yang cukup baik. Nilai rata-rata pertumbuhan kebutuhan selama lima tahun sebesar $4,93 \%$ dan nilai rata-rata pertumbuhan produksi sebesar 3,81\% (Kementrian Pertanian RI, 2015). Hal tersebut 
menunjukkan bahwa rata-rata pertumbuhan kebutuhan lebih tinggi dibandingkan dengan rata-rata pertumbuhan produksi (Direktorat Jenderal Hortikultura, 2014).

Buah-buahan merupakan produk pertanian strategis yang senantiasa tersedia sepanjang tahun. Sifat dan kandungan zat gizi buah digolongkan sebagai bahan pangan yang mudah rusak atau busuk. Pertumbuhan paling pesat selama lima tahun terakhir adalah buah jambu biji dengan persentase pertumbuhan 1,12\% (BPS, 2014). Perkembangan yang pesat mengenai produksi Jambu Biji di Indonesia ini tersebar diberbagai daerah nusantara, salah satunya adalah Bali.

Rata-rata produksi buah di bali dari tahun 2010 s.d. 2014 mencapai 6,57\% salah satu buah-buahan yang memiliki prospek peningkatan yang baik adalah buah Jambu Biji. Rata-rata pertumbuhan produksinya mencapai 3,67\%, angka tersebut mencapai setengah dari rata-rata pertumbuhan buah di Bali (Dinas Pertanian Tanaman Pangan Provinsi Bali, 2014). Produsen buah di Bali tentunya harus bekerjasama dengan perusahaan yang dapat memasarkan hasil produksinya, salah satunya adalah CV Moena Abadi Sejahtera1. Penjualan rata-rata Jambu Biji di CV Moena Abadi Sejahtera 1 sangat kecil dibandingkan dengan empat komoditas lainnya yaitu Salak Bali, Jambu Biji Merah, Pisang Ambon, Jeruk Lumajang, dan Jeruk Kintamani. Selain itu, perusahaan CV Moena Abadi Sejahtera 1 yang berdiri dari tahun 1987 dan tetap berjalan eksis hingga kurang lebih 29 tahun ini perlu dipertahankan.

Berdasarkan uraian diatas dalam upaya mengoptimalkan produksi buah Jambu Biji Merah, maka studi mengenai peramalan penjualan perlu dilakukan. Hal ini mendorong dilakukan penelitian mengenai faktor-faktor yang mempengaruhi penjualan buah Jambu Merah dan estimasi penjualan buah Jambu Biji Merah beberapa tahun kedepan di CV Moena Abadi Sejahtera 1.

\subsection{Rumusan Masalah}

Berdasarkan latar belakang tersebut maka dapat dirumuskan masalah sebagai berikut.

1. Faktor-faktor apa saja yang mempengaruhi secara positif dan negatif volume penjualan buah Jambu Biji Merah pada CV Moena Abadi Sejahtera 1?

2. Bagaimana perkembangan volume penjualan buah Jambu Biji Merah tahun 2016, 2017, dan 2018 mendatang pada CV Moena Abadi Sejahtera 1?

\subsection{Tujuan Penelitian}

Berdasarkan rumusan masalah, adapun tujuan dari penelitian ini sebagai berikut.

1. Mengetahui faktor-faktor yang mempengaruhi secara positif dan negatif volume penjualan buah Jambu Biji Merah pada CV Moena Abadi Sejahtera 1.

2. Mengestimasi volume penjualan buah Jambu Biji Merah tahun 2016, 2017, dan 2018 mendatang pada CV Moena Abadi Sejahtera 1. 


\section{Metode Penelitian}

\subsection{Lokasi dan Waktu Penelitian}

Penelitian ini dilakukan di CV Moena Abadi Sejahtera 1 Jl. Padma Gg. Kampus Ngurah Rai No. 22 Penatih Denpasar. Pemilihan tempat penelitian ini dilakukan dengan sengaja (purposive) dengan pertimbangan bahwa CV Moena Abadi Sejahtera 1 merupakan salah satu perusahan pemasar buah segar terbesar dengan memiliki sembilan outlet tersebar di berbagai kota-kota besar di Bali.

\subsection{Data dan Metode Pengumpulan Data}

Data dalam penelitian ini berupa Data primer diperoleh dari data pola penjualan buah Jambu Biji Merah yang telah dilakukan oleh CV Moena Abadi Sejahtera 1 selama enam tahun terakhir yaitu pada periode Januari 2010 s.d. Desember 2015. Data yang dikumpulkan meliputi volume jual dan harga jual buah Jambu Biji Merah, Salak Bali, Pisang Ambon, Jeruk Lumajang, dan Jeruk kintamani serta informasi lain yang mendukung penelitian (Moena Fresh, 2015).

\subsection{Informan kunci}

Penelitian ini hanya menggunakan informan kunci, yaitu orang yang benar benar menguasai masalah dan terlibat langsung dengan masalah penelitian. Informan kunci pada penelitian ini adalah Putu Tantri selaku manajer.

\subsection{Variabel Penelitian}

Konsep variabel yang digunakan dalam penelitian ini adalah konsep fungsi dan estimasi volume penjualan kemudian dijabarkan dalam bentuk variabel bebas dan variabel terikat. Variabel terikat dalam penelitian kali ini adalah volume jual buah Jambu Biji Merah (QJBM), sedangkan variabel bebas adalah waktu (t), harga Jambu Biji Merah ( $\left.\mathrm{P}_{\mathrm{JBM}}\right)$, harga Salk Bali $\left(\mathrm{P}_{\mathrm{SB}}\right)$, harga Pisang Ambon $\left(\mathrm{P}_{\mathrm{PA}}\right)$, harga Jeruk Lumajang $\left(\mathrm{P}_{\mathrm{JL}}\right)$, dan harga Jeruk Kintamani ( $\mathrm{PJK}_{\mathrm{JK}}$ (Aritonang, 2009).

\subsection{Metode Analisis Data}

\subsubsection{Faktor-faktor yang mempengaruhi volume jual Jambu Biji merah}

Mengestimasi faktor-faktor yang mempengaruhi volume penjualan Buah Jambu Biji Merah digunakan dua model fungsi penjualan yaitu fungsi penjualan yang ditransformasi (Log) dan fungsi penjualan linier.

Fungsi penjualan pertama yaitu penjualan dalam bentuk Log ditulis sebagai berikut.

$\log \mathrm{Q}_{\mathrm{JBM}}=\log b_{0}+b_{1} \log \mathrm{P}_{\mathrm{JBM}}+b_{2} \log \mathrm{P}_{\mathrm{SL}}+b_{3} \log \mathrm{P}_{\mathrm{PA}}$

$$
+b_{4} \log \mathrm{P}_{\mathrm{JL}}+b_{5} \log \mathrm{P}_{\mathrm{JK}}+\mathrm{e}
$$

Fungsi penjualan kedua dalam bentuk regresi linier ditulis sebagai berikut.

$\mathrm{Q}_{\text {JBM }}=\mathrm{f}\left(\mathrm{P}_{\mathrm{JBM}}, \mathrm{P}_{\mathrm{SL}}, \mathrm{P}_{\mathrm{PA}}, \mathrm{P}_{\mathrm{JL}}, \mathrm{P}_{\mathrm{JK}}\right)$

$$
=b o+b_{1} P_{J B M}+b_{2} P_{S L}+b_{3} P_{P A}+b_{4} P_{J L}+b_{5} P_{J K}+e
$$

Keterangan:

Qлвм : Penjualan buah Jambu Biji Merah (kg/bulan)

PJBM : Harga jual buah Jambu Biji Merah (rp/kg) 


$\begin{array}{ll}\mathrm{P}_{\mathrm{SL}} & \text { : Harga jual buah Salak Bali }(\mathrm{rp} / \mathrm{kg}) \\ \mathrm{P}_{\mathrm{PA}} & \text { : Harga jual buah Pisang Ambon }(\mathrm{rp} / \mathrm{kg}) \\ \mathrm{P}_{\mathrm{JL}} & \text { : Harga jual buah Jeruk Lumajang }(\mathrm{rp} / \mathrm{kg}) \\ \mathrm{PJK}_{\mathrm{JK}} & \text { : Harga jual buah Jeruk Kintamani }(\mathrm{rp} / \mathrm{kg}) \\ \mathrm{b} 0 & \text { : Konstanta } \\ \mathrm{e} & \text { : Error } \\ \mathrm{b}_{1}, \mathrm{~b}_{2}, \mathrm{~b}_{3}, \mathrm{~b}_{4}, \mathrm{~b}_{5} & \text { : Koefisien regresi }\end{array}$

kedua fungsi diatas selanjutnya dilakukan uji berdasarkan kriteria statistik dengan nilai $\mathrm{R}^{2}$ (Koefisien determinasi), uji $\mathrm{F}$ (uji ragam), dan uji t (uji koefisien regresi) yang memenuhi kriteria dan dipilih sebagai fungsi penjualan terbaik.

\subsubsection{Metode Peramalan Buah Jambu Biji Merah}

\section{A. Analisis metode peramalan}

Metode peramalan buah Jambu Biji Merah dibedakan menjadi dua yaitu dengan metode analisis tren dan metode peramalan regresi berganda. Metode analisis tren dibagi menjadi empat yaitu metode regresi linier sederhana, kuadratik, ekponensial, dan polinomial, ditulis sebagai berikut (widyantara,2012).

Tabel 1.

Metode Peramalan

\begin{tabular}{ll}
\hline Metode Peramalan & \multicolumn{1}{c}{ Fungsi Peramalan } \\
\hline linier sederhana & Q $_{\mathrm{JBM}}=\mathrm{b} 0+\mathrm{b} 1 \mathrm{t}+\varepsilon$ \\
kuadratik & $\mathrm{Q}_{\mathrm{JBM}}=\mathrm{b} 0+\mathrm{b} 1 \mathrm{t}+\mathrm{b} 2 \mathrm{t} 2+\mathrm{e}$ \\
eksponensial & $\mathrm{Log}_{\mathrm{JBM}}=\mathrm{abx}$ \\
& $\mathrm{Q}_{\mathrm{JBM}}=\mathrm{b} 0+\mathrm{b} 1 \mathrm{t}+\mathrm{b} 2 \mathrm{t} 2+\mathrm{b} 3 \mathrm{t} 3+\ldots \ldots \ldots . .+\mathrm{b} n t \mathrm{tn}+\mathrm{e}$ \\
Polinomial & $\mathrm{Q}_{\mathrm{JBM}}=\mathrm{b} 0+\mathrm{b}_{1} \mathrm{Q}_{\mathrm{SL}}+\mathrm{b}_{2} \mathrm{Q}_{\mathrm{PA}}+\mathrm{b}_{3} \mathrm{Q}_{\mathrm{JL}}+\mathrm{b}_{4} \mathrm{Q}_{\mathrm{JK}} \pm \mathrm{e}$ \\
Berganda & \\
\hline
\end{tabular}

Keterangan :



\section{B. Ukuran akurasi peramalan}

Secara sederhana, ukuran akurasi peramalan dapat diketahui dengan memiliki nilai $\mathrm{R}^{2}$ terbesar dan nilai Se (Standart error) terendah. Semakin besar Se, ini berarti prediksi yang akan dilakukan semakin tidak akurat.

\section{Hasil dan Pembahasan}

\subsection{Identifikasi Model Fungsi Penjualan Buah Jambu Biji Merah}

Penelitian ini menggunakan dua model fungsi penjualan yaitu fungsi penjualan yang ditransformasikan ke dalam bentuk Log dan fungsi penjualan linier berganda. Adapun hasil pengujian menggunakan kriteria statistik dapat dilihat pada Tabel 2. 
Tabel 2.

Hasil Uji Statistik

\begin{tabular}{|c|c|c|c|}
\hline \multirow{2}{*}{ Fungsi Penjualan } & \multicolumn{2}{|c|}{ Uji Statistik } & \multirow{2}{*}{ Keterangan } \\
\hline & Uji R & Uji F & \\
\hline Linier berganda & 0,515 atau $51,5 \%$ & Sig. $=0,001$ & Signifikan \\
\hline Transformasi (Log) & 0,793 atau $79,3 \%$ & Sig. $=0,001$ & Signifikan \\
\hline
\end{tabular}

Signifikan (P-Value $<0,05)$

Tidak signifikan $(\mathrm{P}-$ Value $>0,05)$

1. Berdasarkan hasil analisis, nilai $\mathrm{R}^{2}$ pada model fungsi penjualan regresi linier berganda yaitu sebesar 51,5\% memiliki arti bahwa variabel bebas berpengaruh sebesar 51,5\% terhadap variabel penjualan Buah Jambu Biji Merah, sedangkan sisanya sebesar 48,5\% dipengaruhi oleh variabel lain yang tidak dimasukkan kedalam penelitian ini. Nilai $\mathrm{R}^{2}$ fungsi penjualan yang ditransformasikan ke dalam bentuk Log sebesar 79,3\% memiliki arti bahwa variabel bebas berpengaruh sebesar 79,3\% terhadap variabel penjualan Buah Jambu Biji Merah, sedangkan sisanya sebesar 20,7\% dipengaruhi oleh variabel lain yang tidak dimasukkan kedalam penelitian.

2. Nilai P-Value pada uji F-hitung kedua fungsi permintaan sama-sama memiliki nilai sebesar 0,000. Nilai ini P-value lebih kecil dari $\alpha=0,05$ artinya variabel bebas secara simulan mampu menerangkan varibel terikat.

3. Uji t (Uji Parsial) digunakan untuk menguji secara parsial/masing-masing variabel. Uji t diperlukan untuk mengetahui variabel bebas apa saja yang mempengaruhi variabel terikat. Hasil analisis dapat dilihat pada Tabel 3.

Tabel 3.

Hasil Uji t

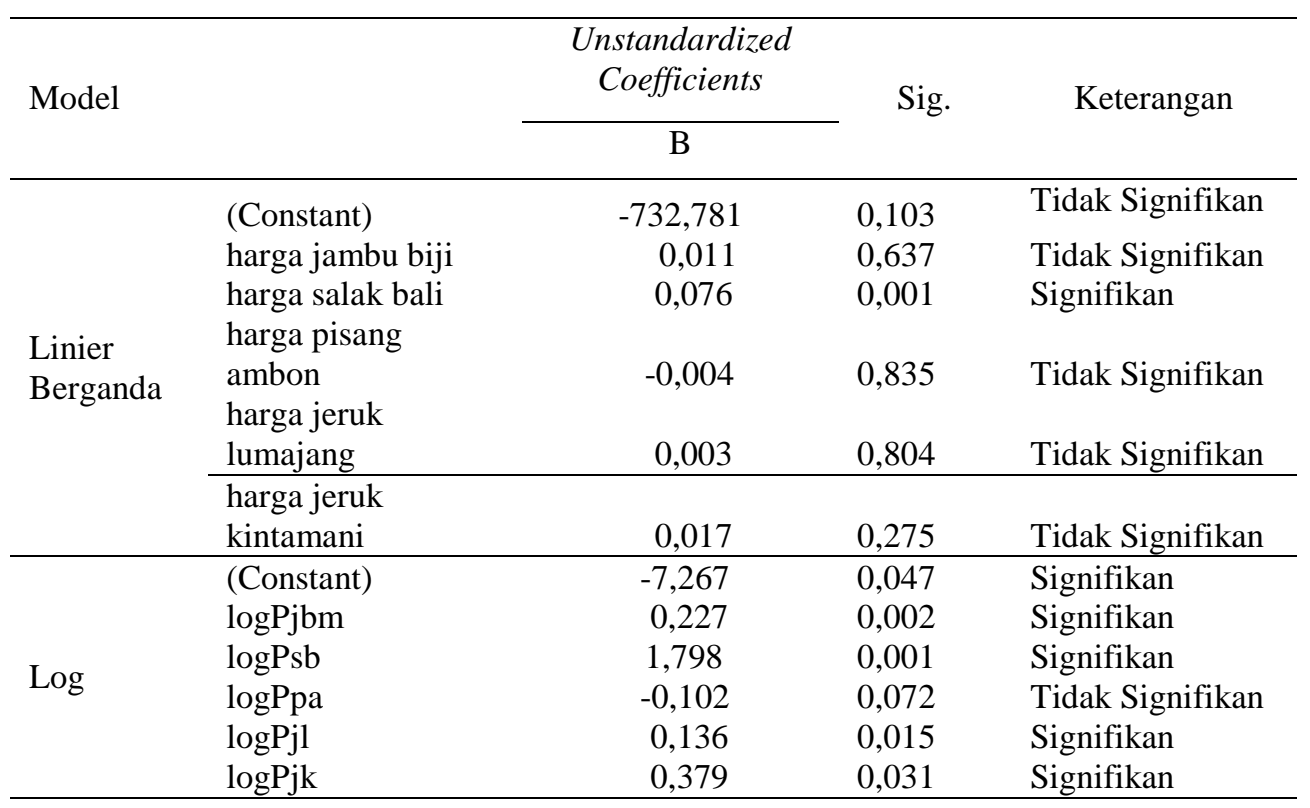


Hasil analisis diatas menujukkan bahwa model yang dtransforrmasikan hanya memiliki satu variabel bebas yang tidak signifikan yaitu variabel harga Pisang Ambon $\left(\mathrm{P}_{\mathrm{PA}}\right)$, sedangkan pada model linier berganda terdapat empat variabel bebas yang tidak signifikan yaitu $\mathrm{P}_{\mathrm{JBM}}, \mathrm{P}_{\mathrm{PA}}, \mathrm{P}_{\mathrm{JL}}, \mathrm{P}_{\mathrm{JK}}$.

Berdasarkan ketiga uji statistik diatas, maka dipilih fungsi penjualan yang ditransformasikan dalam bentuk Log untuk ditetapkan sebagai model yang representatif mewakili fungsi penjualan Buah Jambu Biji Merah CV Moena Sejahtera 1 (Tenaya, 2009).

\subsection{Faktor yang Mempengaruhi Penjualan Buah Jambu Biji Merah}

Faktor-faktor yang mempengaruhi penjualan buah Jambu Biji Merah akan dianalisis melalui persamaan fungsi yang dtransformasikan terdiri dari beberapa peubah bebas yang telah diidentifikasi yaitu, harga Buah Jambu Biji $\left(\mathrm{P}_{\mathrm{JBM}}\right)$, harga Buah Salak Bali $\left(\mathrm{P}_{\mathrm{SB}}\right)$, harga Buah Pisang Ambon $\left(\mathrm{P}_{\mathrm{PA}}\right)$, harga Buah Jeruk Lumajang $\left(\mathrm{P}_{\mathrm{JL}}\right)$, dan harga Buah Jeruk Kintamani $\left(\mathrm{P}_{\mathrm{JK}}\right)$. Hasil dari analisis faktor-faktor yang mempengaruhi penjualan Buah Jambu Biji Merah. Hasil analisis dapat dilihat pada Tabel 4.

Tabel 4.

Faktor-faktor yang Mempengaruhi penjualan Buah Jambu Biji Merah

\begin{tabular}{lrrrl}
\hline Faktor Penjualan & Koefisien & Std. Error & \multicolumn{1}{c}{ S } & \multicolumn{1}{l}{ Sig. } \\
\hline Konstanta & $-7,267$ & 8,255 & $-2,027$ & 0,047 \\
Harga Buah Jambu Biji Merah & $-0,227$ & 0,434 & 0,524 & 0,002 \\
Harga Buah Salak Bali & 1,798 & 0,494 & 3,638 & 0,001 \\
Harga Buah Pisang Ambon & $-0,102$ & 0,830 & $-0,123$ & 0,072 \\
Harga Buah Jeruk Lumajang & 0,136 & 0,580 & 0,235 & 0,015 \\
Harga Buah Jeruk Kintamani & 0,379 & 0,421 & 0,901 & 0,031 \\
\hline R (koefisien determinasi) =79,3\% & \multicolumn{4}{c}{ Adjusted R-Square = 33,7\% } \\
\hline F Hitung = 51,3343 & \multicolumn{4}{c}{ Sig. (Uji F) = 0,001 } \\
\hline
\end{tabular}

Berdasarkan hasil analisis, maka diperoleh persamaan sebagai berikut. $\log \mathrm{Q}_{\mathrm{JBM}}=-7,267-0,227 \log \mathrm{P}_{\mathrm{JBM}}+1,798 \log \mathrm{P}_{\mathrm{SB}}-0,102 \log \mathrm{P}_{\mathrm{PA}}+$

$$
0,136 \log \mathrm{P}_{\mathrm{JL}}+0,379 \log \mathrm{P}_{\mathrm{JK}}
$$

Faktor $\mathrm{P}_{\mathrm{JBM}}$ yaitu harga Buah Jambu Biji Merah memiliki nilai koefisien yaitu sebesar $-0,227$. Nilai sebesar $-0,227$ pada koefisien PJBM berarti bahwa jika harga Buah Jambu Biji Merah naik sebesar satu persen maka permintaan akan Jambu Biji Merah turun sebesar 0,227\% dan sebaliknya dengan asumsi jika faktor lain yang mempengaruhi tetap (Cateris paribus).

Faktor $\mathrm{P}_{\mathrm{SB}}$ yaitu harga Buah Salak Bali memiliki nilai koefisien yaitu sebesar $+1,798$. Tanda positif pada nilai koefisien $P_{S B}$ menunjukan bahwa faktor $P_{S B}$ berpengaruh positif terhadap penjualan Buah Jambu Biji Merah. Hal ini berarti Buah 
Salak Bali bersifat produk substitusi, nilai sebesar 1,798 pada koefisien $\mathrm{P}_{\mathrm{SB}}$ berarti bahwa jika harga Buah Salak Bali naik sebesar satu persen maka penjualan akan Buah Jambu Biji Merah naik sebesar 1,798\% dan sebaliknya dengan asumsi jika faktor lain yang mempengaruhi tetap (cateris paribus).

Faktor $\mathrm{P}_{\mathrm{PA}}$ yaitu harga Buah Pisang Ambon memiliki nilai koefisien yaitu sebesar $-0,102$. Tanda negatif pada nilai koefisien $P_{P A}$ menunjukan bahwa faktor $P_{P A}$ berpengaruh negatif terhadap Penjualan Buah Jambu Biji Merah. Hal ini berarti Pisang Ambon bersifat produk komplementer, berarti bahwa jika harga Buah Pisang Ambon naik sebesar satu persen maka penjualan akan Jambu Biji Merah turun sebesar $0,102 \%$ dan sebaliknya dengan asumsi jika faktor lain yang mempengaruhi tetap (cateris paribus).

Faktor $\mathrm{P}_{\mathrm{JL}}$ yaitu harga Buah Jeruk Lumajang memiliki nilai koefisien yaitu sebesar $+0,136$. Tanda positif pada nilai koefisien $\mathrm{P}_{\mathrm{JL}}$ menunjukan bahwa faktor $\mathrm{P}_{\mathrm{JL}}$ berpengaruh positif terhadap penjualan Buah Jambu Biji Merah, berarti bahwa jika harga Buah Jeruk Lumajang naik sebesar satu persen maka penjualan akan Buah Jambu Biji Merah naik sebesar 0,136\% dan sebaliknya dengan asumsi jika faktor lain yang mempengaruhi tetap (cateris paribus).

Faktor $\mathrm{P}_{\mathrm{JK}}$ yaitu harga Buah Jeruk Kintamani memiliki nilai koefisien yaitu sebesar $+0,379$. Tanda positif pada nilai koefisien $\mathrm{P}_{\mathrm{JK}}$ menunjukan bahwa faktor $\mathrm{P}_{\mathrm{JL}}$ berpengaruh positif terhadap penjualan Buah Jambu Biji Merah. Hal ini berarti Buah Jeruk Kintamani bersifat produk substitusi, berarti bahwa jika harga Buah Jeruk Kintamani naik sebesar satu persen maka penjualan akan Buah Jambu Biji Merah naik sebesar 0,379\% dan sebaliknya, dengan asumsi jika faktor lain yang mempengaruhi tetap (cateris paribus).

\subsection{Metode Peramalan Buah Jambu Biji Merah}

Melalui metode peramalan, diharapkan dapat diidentifikasi model yang dapat digunakan untuk meramalkan kondisi pada waktu yang akan datang.

1. Metode analisis tren

Metode tren pada penelitian ini adalah metode regresi linier, kuadratik, eksponensial, dan polinomial. Hasil analisis dapat dilihat pada Tabel 5. 
Tabel 5.

Hasil Analisis Metode Tren

\begin{tabular}{|c|c|c|c|c|c|c|c|}
\hline \multirow{2}{*}{ Metode tren } & \multirow{2}{*}{$\mathrm{R}^{2}$} & \multirow{2}{*}{ Uji F } & \multirow{2}{*}{$\mathrm{Se}$} & \multicolumn{3}{|c|}{ Uji t } & \multirow{2}{*}{ Persamaan } \\
\hline & & & & & B & Sig. & \\
\hline $\begin{array}{l}\text { linier } \\
\text { sederhana }\end{array}$ & $49,0 \%$ & 0,000 & 117,442 & $\begin{array}{l}\text { b0 } \\
\text { b1 }\end{array}$ & $\begin{array}{l}518,625 \\
1,565\end{array}$ & $\begin{array}{l}0,000 \\
0,000\end{array}$ & $\begin{array}{l}\mathrm{Q}_{\text {JBM }}=518,625+ \\
1,565 \mathrm{t} \pm 117,442\end{array}$ \\
\hline \multirow[t]{3}{*}{ kuadratik } & \multirow[t]{3}{*}{$48,2 \%$} & \multirow[t]{3}{*}{0,000} & \multirow[t]{3}{*}{118,096} & b0 & 511,224 & 0,000 & \multirow{3}{*}{$\begin{array}{l}\text { Q } \mathrm{JBM}=511,224+ \\
1,565 \mathrm{t}+0,004 \mathrm{t} 2 \pm \\
118,096\end{array}$} \\
\hline & & & & b1 & 1,565 & 0,000 & \\
\hline & & & & $\mathrm{b} 2$ & 0,004 & 0,036 & \\
\hline \multirow[t]{4}{*}{ polinomial } & \multirow[t]{4}{*}{$52,7 \%$} & \multirow[t]{4}{*}{0,000} & \multirow[t]{4}{*}{116,172} & $\mathrm{~b} 0$ & 511,224 & 0,000 & \multirow{4}{*}{$\begin{array}{l}\text { Q } \\
1,565 \mathrm{t}+0,004 \mathrm{t} 2+ \\
0,034 \mathrm{t} 3 \pm 116,172\end{array}$} \\
\hline & & & & b1 & 2,938 & 0,001 & \\
\hline & & & & $\mathrm{b} 2$ & 0,004 & 0,630 & \\
\hline & & & & b3 & 0,034 & 0,073 & \\
\hline \multirow[t]{2}{*}{ eksponensial } & \multirow[t]{2}{*}{$68,2 \%$} & \multirow[t]{2}{*}{0,000} & \multirow[t]{2}{*}{0,096} & b0 & 2,701 & 0,000 & \multirow[t]{2}{*}{$\begin{array}{l}\text { Q JBM }=2,701 t^{0,001} \pm \\
0,096\end{array}$} \\
\hline & & & & b1 & 0,001 & 0,000 & \\
\hline
\end{tabular}

Signifikan (P-Value $<0,05)$

Tidak signifikan $(\mathrm{P}-$ Value $>0,05)$

Tabel 5 menunjukkan bahwa metode tren eksponensial memiliki nilai $\mathrm{R}^{2}$ terbesar dengan nilai Se terkecil secara berturut-turut yaitu 68,2\% dan 0,096.

2. Metode peramalan regresi berganda

Metode ini menganalisis hubungan antara volume jual Buah Salak Bali, volume jual Buah Pisang Ambon, volume jual Buah Jeruk Kintamani, dan volume jual Jeruk Lumajang sebagai variabel bebas dan volume jual Buah Jambu Biji Merah sebagai variabel terikat.

Tabel 6.

Hasil Uji T Metode Regresi Berganda

\begin{tabular}{|c|c|c|c|c|c|c|c|}
\hline \multirow{2}{*}{ Model } & & \multicolumn{2}{|c|}{$\begin{array}{c}\text { Unstandardized } \\
\text { Coefficients } \\
\end{array}$} & \multirow{2}{*}{ Sig. } & \multirow{2}{*}{$\mathrm{R}^{2}$} & \multirow{2}{*}{$\begin{array}{l}\text { Standar } \\
t \text { Error }\end{array}$} & \multirow{2}{*}{ Keterangan } \\
\hline & & $\mathrm{B}$ & $\begin{array}{c}\text { Std. } \\
\text { Error }\end{array}$ & & & & \\
\hline \multirow{5}{*}{$\begin{array}{l}\text { Regresi } \\
\text { linier } \\
\text { berganda }\end{array}$} & (Constant) & 687,525 & 202,312 & 0,001 & $69,1 \%$ & 199,06 & Signifikan \\
\hline & Qsb & $-0,457$ & 0,191 & 0,020 & & & Signifikan \\
\hline & Qpa & 0,226 & 0,084 & 0,720 & & & TidakSignifikan \\
\hline & Qj1 & $-0,094$ & 0,026 & 0,001 & & & Signifikan \\
\hline & Qjk & 0,110 & 0,022 & 0,520 & & & TidakSignifikan \\
\hline
\end{tabular}

Signifikan (P-Value $<0,05)$

Tidak signifikan $(\mathrm{P}-\mathrm{Value}>0,05)$

Berdasarkan hasil analisis pada Tabel 6 maka diperoleh persamaan metode peramalan regresi berganda, sebagai berikut.

$$
\begin{aligned}
\quad & 687,525-0,547 \mathrm{Q}_{\mathrm{SB}}+0,226 \mathrm{Q}_{\mathrm{PA}}-0,094 \mathrm{Q}_{\mathrm{JL}}+0,110 \mathrm{Q}_{\mathrm{JK}} \\
& \pm 199,06
\end{aligned}
$$




\subsection{Menentukan Metode Peramalan Terbaik}

Menurut Firdaus (2006), secara sederhana dapat diketahui bahwa semakin besar se, berarti semakin besar selisih antara data yang ada (yang sesungguhnya) dan nilai proyeksinya. Selain melihat nilai Se, ukuran akurasi peramalan dalam penelitian kali ini juga dilihat dari nilai $\mathrm{R}^{2}$. Semakin besar nilai $\mathrm{R}^{2}$ maka semakin baik. Hasil ukuran akurasi peramalan dapat dilihat pada Tabel 7.

Tabel 7.

Ukuran Akurasi Peramalan

\begin{tabular}{|c|c|c|c|}
\hline Model peramalan & $\mathrm{R}^{2}$ & SE & Fungsi peramalan \\
\hline Linier Sederhana & $49,0 \%$ & 117,44 & $\mathrm{Q}=518,625+1,625 \mathrm{t} \pm \mathrm{e}$ \\
\hline Kuadratik & $49,2 \%$ & 118,09 & $\mathrm{Q}=511,224+1,656 \mathrm{t}+0,004 \mathrm{t}^{2} \pm \mathrm{e}$ \\
\hline Polynomial & $52,7 \%$ & 116,17 & $\mathrm{Q}=511,224+2,938 \mathrm{t}+0,004 \mathrm{t}^{2}+0,034 \mathrm{t}^{3} \pm \mathrm{e}$ \\
\hline Tren Eksponensial & $68,2 \%$ & 0,10 & $\mathrm{Q}=2,701 \mathrm{X}^{0,001} \pm \mathrm{e}$ \\
\hline Berganda & $71,1 \%$ & 199,06 & $\begin{array}{l}\mathrm{Q}=687,525-0,547 \mathrm{Q}_{\mathrm{SB}}+0,226 \mathrm{Q}_{\mathrm{PA}}-0,094 \mathrm{Q}_{\mathrm{JL}}+ \\
0,110 \mathrm{Q}_{\mathrm{JK}} \pm 199,06\end{array}$ \\
\hline
\end{tabular}

Hasil ukuran akurasi peramalan pada Tabel 7 menunjukkan bahwa Metode peramalan yang memiliki nilai Se terkecil dan nilai $\mathrm{R}^{2}$ terbesar adalah metode peramalan tren eksponensial dengan nilai berturut-turut 0,10 dan $68.2 \%$. Jadi atas dasar tersebut maka dipilih metode peramalan tren eksponensial untuk ditetapkan sebagai metode peramalan kuantitatif terbaik.

\subsection{Estimasi Penjualan buah Jambu Biji Merah tahun 2016 s.d. 2018}

Metode peramalan tren eksponensial digunakan untuk memperoleh estimasi peramalan volume penjualan buah Jambu Biji Merah dari tahun 2016 s.d. 2018. Fungsi peramalan tren eksponensial dalam penelitian ini adalah $\mathrm{Y}=502,34+1,0023$ $\mathrm{t} \pm \mathrm{e}$. Nilai standart error adalah 0,01 (Wirakusumah, 2010). Hasil estimasi volume penjualan dapat dilihat pada Tabel 8 . 
Tabel 8.

Estimasi Volume Penjualan Buah Jambu Biji Merah

Tahun 2016, 2017, dan 2018

\begin{tabular}{lccc}
\hline Bulan & \multicolumn{3}{c}{ Tahun } \\
& \multicolumn{3}{c}{$(\mathrm{kg})$} \\
\cline { 2 - 4 } Januari & 5016 & 2017 & 2018 \\
Februari & 577,50 & 599,56 & 623,62 \\
Maret & 579,52 & 601,57 & 625,63 \\
April & 581,52 & 603,57 & 627,63 \\
Mei & 583,53 & 607,58 & 629,63 \\
Juni & 585,53 & 609,59 & 631,64 \\
Juli & 587,54 & 611,59 & 635,65 \\
Agustus & 589,54 & 613,60 & 637,65 \\
September & 591,55 & 615,60 & 639,66 \\
Oktober & 593,55 & 617,60 & 641,69 \\
November & 595,55 & 619,61 & 643,66 \\
Desember & 597,56 & 621,61 & 645,67 \\
\hline Jumlah & 7038,34 & 7327.61 & 7615,72 \\
\hline rata-rata & 586,53 & 610,59 & 634,64 \\
\hline
\end{tabular}

Hasil pada Tabel 8 menunjukan Rata-rata estimasi penjualan Jambu Biji Merah tahun 2016, 2017, dan 2018 berturut-turut sebesar 586,53 kg, 610,59 kg, dan 634,64 kg. Hal tersebut menunjukkan adanya peningkatan penjualan Jambu Biji Merah.

\section{Simpulan dan Saran}

Berdasarkan atas hasil analisis yang telah dilakukan terhadap penjualan Buah Jambu Biji Merah di CV Moena Abadi Sejahtera 1 dengan menggunakan perangkat lunak SPSS 20, maka dapat disimpulkan faktor-faktor yang mempengaruhi penjualan Buah Jambu Biji Merah di CV Moena Abadi Sejahtera 1 secara positif adalah buah Salak Bali, Jeruk Lumajang, dan Jeruk Kintamani serta secara negatif adalah buah Jambu Biji Merah dan Pisang Ambon. Jumlah estimasi volume penjualan Buah Jambu Biji Merah di CV Moena Abadi Sejahtera 1 tahun 2016, 2017, dan 2018 terus meningkat.

\section{Ucapan Terimakasih}

Ucapan terimakasih penulis tujukan kepada seluruh pihak yang telah membantu dalam pelaksanaan penelitian yang telah membantu dalam penyempurnaan e-jurnal ini hingga bisa dipublikasikan. 


\section{Daftar Pustaka}

Aritonang R, Lerbin R. 2009. Peramalan Bisnis. Lembaga penerbit Ghalia Indonesia, Jakarta.

Badan Pusat Statistik. 2014. Tingkat Kebutuhan dan Produksi Buah-buahan di Indonesia Tahun 2010 s.d. 2014. http://badanpusatstatistik.com/. diunduh pada tanggal 3 Maret 2016.

Dinas Pertanian Tanaman Pangan Provinsi Bali. 2014. Produksi Buah-Buahan di Provinsi Bali. Dinas Pertanian, Bali. http://distanprovinsibali.com/. diunduh pada tanggal 21 Februari 2016.

Direktorat Jenderal Hortikultura. 2014. Tingkat Kebutuhan dan Produksi Buahbuahan di Indonesia Tahun 2010 s.d. 2014. http://distanprovinsibali.com/. diunduh pada tanggal 3 Maret 2016.

Firdaus. 2006. Menentukan Metode Peramalan Terbaik. Jakarta. https://eprints.uns.ac.id/.pdf. diunduh pada tanggal 3 Maret 2016.

Kementrian Pertanian RI. 2015. Luas Panen Buah-Buahan di Indonesia. Jakarta: Kementrian Pertanian. www.pertanian.go.id/ap_pages/mod/datahort. diunduh pada tanggal 14 Februari 2015.

Moena Fresh. 2015. Laporan Volume Penjualan Buah-buahan CV Moena Abadi Sejahtera 1, Maret 2015. Denpasar.

Tenaya, Narka. 2009. Ekonometrika Program Studi Agribisnis. Bahan Ajar Ekonometrika Program Studi Agribisnis Laboratorium Statistika Fakultas Pertanian Universitas Udayana. Denpasar.

Widyantara, Wayan. 2012. Peramalan Bisnis. Bahan Ajar Mata Kuliah Peramalan Bisnis Program Studi Agribisnis Fakultas Pertanian Universitas Udayana. Denpasar.

Wirakusumah. 2010. Manfaat Jambu Biji Merah. USU, Surabaya. http://repository.usu.ac.id/.pdf. diunduh pada tanggal 29 Februari 2016. 